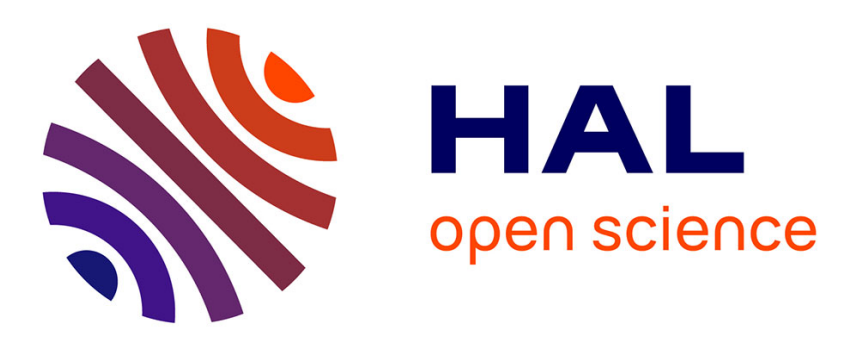

\title{
Prevalence and herd-level risk factors for intramammary infection with coagulase-negative staphylococci in Dutch dairy herds
}

\author{
O.C. Sampimon, H.W. Barkema, I.M.G.A. Berends, J. Sol, T.J.G.M. Lam
}

\section{- To cite this version:}

O.C. Sampimon, H.W. Barkema, I.M.G.A. Berends, J. Sol, T.J.G.M. Lam. Prevalence and herd-level risk factors for intramammary infection with coagulase-negative staphylococci in Dutch dairy herds. Veterinary Microbiology, 2009, 134 (1-2), pp.37. 10.1016/j.vetmic.2008.09.010 . hal-00532478

\section{HAL Id: hal-00532478 https://hal.science/hal-00532478}

Submitted on 4 Nov 2010

HAL is a multi-disciplinary open access archive for the deposit and dissemination of scientific research documents, whether they are published or not. The documents may come from teaching and research institutions in France or abroad, or from public or private research centers.
L'archive ouverte pluridisciplinaire HAL, est destinée au dépôt et à la diffusion de documents scientifiques de niveau recherche, publiés ou non, émanant des établissements d'enseignement et de recherche français ou étrangers, des laboratoires publics ou privés. 


\section{Accepted Manuscript}

Title: Prevalence and herd-level risk factors for intramammary infection with coagulase-negative staphylococci in Dutch dairy herds

Authors: O.C. Sampimon, H.W. Barkema, I.M.G.A. Berends,

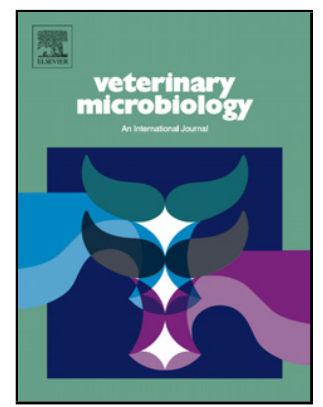
J. Sol, T.J.G.M. Lam

PII: S0378-1135(08)00362-3

DOI: doi:10.1016/j.vetmic.2008.09.010

Reference: VETMIC 4147

To appear in: $\quad$ VETMIC

Please cite this article as: Sampimon, O.C., Barkema, H.W., Berends, I.M.G.A., Sol, J., Lam, T.J.G.M., Prevalence and herd-level risk factors for intramammary infection with coagulase-negative staphylococci in Dutch dairy herds, Veterinary Microbiology (2008), doi:10.1016/j.vetmic.2008.09.010

This is a PDF file of an unedited manuscript that has been accepted for publication. As a service to our customers we are providing this early version of the manuscript. The manuscript will undergo copyediting, typesetting, and review of the resulting proof before it is published in its final form. Please note that during the production process errors may be discovered which could affect the content, and all legal disclaimers that apply to the journal pertain. 
1 Prevalence and herd-level risk factors for intramammary infection with coagulase2 negative staphylococci in Dutch dairy herds

3

4 O.C. Sampimon ${ }^{\mathrm{a},}{ }^{*}$, H.W. Barkema ${ }^{\mathrm{b}}$, I.M.G.A. Berends ${ }^{\mathrm{a}}$, J. Sol ${ }^{\mathrm{a}}$ and T.J.G.M. Lam ${ }^{\mathrm{a}, \mathrm{c}}$

$5 \quad{ }^{\mathrm{a}}$ GD Animal Health Service, Deventer, The Netherlands

$6{ }^{b}$ Dept. of Production Animal health, Faculty of Veterinary Medicine, University of Calgary,

7 Calgary, AB, Canada

$8 \quad{ }^{\mathrm{c}}$ Dutch Udder Health Centre, Deventer, The Netherlands

9

$10 *$ Corresponding author: O.C. Sampimon, GD Animal Health Service, Arnsbergstraat 7, PO

11 Box 9, 7400 AA Deventer, The Netherlands, tel. +31 570660367, fax. +31 570660345, e12 mail: o.sampimon@gddeventer.com 


\section{Abstract}

In this study, the prevalence of intramammary infection (IMI) with coagulase-negative staphylococci (CNS) in The Netherlands was estimated on 49 randomly selected herds with at least 40 lactating cows. In total, 4220 quarter milk samples were collected. The prevalence of CNS IMI in The Netherlands was estimated at $10.8 \%$ at quarter level and $34.4 \%$ at cow level, making it the most frequently isolated group of pathogens. Fourteen species of CNS were identified; the most frequently isolated species was Staphylococcus chromogenes $(30.3 \%)$ followed by Staphylococcus epidermidis (12.9\%) and Staphylococcus capitis $(11.0 \%)$. Prevalence of CNS IMI was higher in heifers compared to older cows. Geometric mean quarter SCC of CNS-positive quarters was 109,000 cells/ml, which was approximately twice as high as culture-negative quarters. Quarters infected with $S$. chromogenes, S. capitis and Staphylococcus xylosus had a higher SCC $(P<0.05)$ than culture-negative quarters, while quarters that were culture-positive for S. epidermidis and Staphylococcus hyicus tended to have a higher SCC than culture-negative quarters. An increased prevalence of CNS IMI was associated with the herd level variables source of drinking water not being tap water, housing of dry cows in one group instead of multiple groups, measurement of cow SCC every month, udder health monitoring by the veterinarian, pasturing during outdoor season, percentage of stalls contaminated with milk, and BMSCC $>250,000$ cells $/ \mathrm{ml}$. Although a causal relation between these factors and prevalence of CNS is not proven and for some factors not even likely, knowledge of the associations found may by helpful when approaching CNS problems on dairy farms.

Key words: Mastitis; Bovine; Prevalence; Risk factors; Coagulase-negative staphylococci 


\section{Introduction}

(n)

Mastitis is one of the most important diseases in dairy cattle, resulting in significant losses (Halasa et al., 2007). It is a multifactorial disease which is hard to manage, and numerous management factors, such as housing facilities, milking procedures, feeding programmes, treatment regimes and others influence udder health on a dairy farm. More than 100 bacterial species can cause bovine mastitis (Smith and Hogan, 2001). At the herd level it is important to know which pathogens are involved in clinical and subclinical mastitis, to be able to implement the correct management practices in case of an udder health problem. Also at a population level, it is important to know which pathogens are the most important ones, and what their antibiotic sensitivity pattern is. This can help advisors in choosing the right strategy in problem solving and in giving specific preventive advice.

Coagulase-negative staphylococci (CNS) are historically considered to be minor mastitis pathogens and are frequently not reported in mastitis studies (Bramley et al., 1984). However, CNS are isolated from cases of subclinical and clinical mastitis, and also from teat canals, teat skin and teat ducts (Devriese and Keyser, 1979; Barkema et al., 1998; De Vliegher et al., 2003; Bradley et al., 2007; Sampimon et al., 2007a). Additionally, CNS are the most frequently isolated pathogens in heifer mastitis (Trinidad et al., 1990; Matthews et al., 1991). Recently, several prevalence studies have been performed around the world. In almost all studies CNS were the most frequently isolated group of species from milk samples of cows with high SCC (Pitkälä et al., 2004; Bradley et al., 2007; Piepers et al., 2007). However, prevalence of CNS IMI in Dutch dairy herds has never been quantified.

Control programmes such as the "five-point program" work well for control of intramammary infections (IMI) with contagious major pathogens such as Staphylococcus aureus and Streptococcus agalactiae (Neave at al., 1969, Sampimon et al., 2007b). However, 
1 these programs seem to be less effective to reduce prevalence of CNS IMI (Taponen and

2 Pyörälä, 2007). As a result of the decrease of the prevalence of IMI with contagious major

3 pathogens, CNS have become relatively more important. Although CNS have not been proven

4 causal in all mastitis cases, they are considered as the leading cause of subclinical mastitis on

5 most dairy farms implementing mastitis control practices (Harmon and Langlois, 1995).

6 However, in other studies CNS had a protective effect on IMI with major pathogens (Lam et

7 al., 1997b; De Vliegher et al., 2004). Factors such as parity, stage of lactation, breed and

8 numerous management practices can influence the prevalence of a specific pathogen. These

9 factors, however, have rarely been studied in relation to CNS.

The aim of this study was to determine the prevalence of IMI with CNS in Dutch dairy

11 cows, and possible herd-level risk factors.

12

13

\section{Materials and Methods}

\subsection{Herds and cows}

Data were obtained from a national subclinical mastitis prevalence study of 49 herds of at least 40 lactating cows. Herds were stratified by province (12 provinces), and the number of randomly selected herds per province was proportional to the total number of herds per province that had at least 40 lactating cows. To select a representative sample of the population it was calculated that approximately 50 herds were needed (Sampimon et a., 2007b). A total of 61 herds was selected and 49 agreed to participate in the study. These herds were sampled across the period of the study within regions. Based on the currently used cutoff levels in The Netherlands by the Dutch DHI, all quarters of high SCC (HSCC) cows 
$1 \quad(\mathrm{SCC}>250,000$ cells $/ \mathrm{ml})$ and heifers $(\mathrm{SCC}>150,000$ cells $/ \mathrm{ml})$ were sampled. Additionally, a

2 subset of approximately $25 \%$ of cows and heifers with a low SCC (LSCC), cows

3 (SCC $\leq 250,000$ cells $/ \mathrm{ml})$ and heifers $(\mathrm{SCC} \leq 150,000$ cells $/ \mathrm{ml})$, which were randomly selected

4 were sampled once. The milk samples were collected within one week after arrival of the milk

5 recording results on the farm. Cows that were dried off, culled or treated with antibiotics in

6 the mean time were excluded from sampling. Samples were collected between April 2003 and

7 September 2004. Selected cows were sampled during regular milking times. Pre-milking

8 udder preparation with a cotton or paper towel was carried out by the farmer. All samples

9 were collected according to the NMC protocol by trained personnel of the GD Animal Health

10 Service (GD) in Deventer, The Netherlands. Teat ends were disinfected with a cotton swab

11 soaked in methylated alcohol, and after the third stripping, milk was collected. The milk samples were transported on ice to the GD for bacteriology and determination of SCC. Bulk milk SCC was measured once, in a period two weeks before the sampling of the individual cows.

\subsection{Laboratory Analyses}

The samples were split and SCC was determined using a Fossomatic cell counter (Foss Electric, Hillerød, Denmark). Bacteriological culturing was carried out according to the NMC protocol (Harmon et al., 1990). Major pathogens were considered to cause an IMI if $\geq 100 \mathrm{cfu} / \mathrm{ml}$ was isolated, while isolation of $\geq 500 \mathrm{cfu} / \mathrm{ml}$ of a minor pathogen was defined as an IMI. A colony of CNS was distinguished from S. aureus using Slidex Staphytect Plus (Oxoid, UK). Milk samples from which more than two bacterial species were cultured were considered to be contaminated. Directly after culturing, all milk samples were stored at $-20^{\circ} \mathrm{C}$. From the 530 milk samples in which CNS was found, 160 milk samples were randomly 
1 selected. These samples were thawed at room temperature and then cultured again.

2 Coagulase-negative staphylococci were speciated with the API Staph ID 32 (BioMérieux,

3 Lyon, France) using the procedures recommended by the manufacturer. Probability of the

4 identification result in a range of 10 to $100 \%$ was calculated using the Apilab software.

$5 \quad$ Suggested tests for the delineation of species were executed.

6

7

8

9

\subsection{Questionnaire}

A questionnaire was conducted to obtain information on management factors of the farms such as housing facilities, milking procedures, feeding and treatment regimes. The questionnaire was validated before use at 10 dairy farms. During the farm visit to collect milk samples, the questionnaire was conducted by personnel of GD. The questions were aimed at the the year preceding the sampling date. The items included in the questionnaire are summarized in eight categories of management practices in Table 1.

\subsection{Statistical analysis}

Cow-level prevalence of CNS IMI and 95\% confidence intervals were calculated for the HSCC and LSCC group separately. To determine a national prevalence, the number of sampled quarters within HSCC and LSCC animals was adjusted for the total number of quarters of HSCC and LSCC animals per herd. The prevalence was calculated by means of a General Linear Model (GLM) in Stata (version 9, 2005). In this procedure we could correct for the fact that cows within a herd are more correlated to each other than random cows by adding the herd number as a repeated measurement. The estimate of the result was the corrected prevalence. 
After checking the data for unlikely values the information of the questionnaire was used in a risk factor analysis, by means of a generalized linear model in SAS version 9.1 (SAS, 2004). Prevalence of CNS IMI was calculated and included as dependent variable in the model. All variables where first screened in a univariate analysis. Risk factors with a significant association with the prevalence of CNS IMI at $P$-value $<0.25$ subsequently entered the multivariate analysis. Per class-variable, the biologically most logical class was used as reference. Selection of variables was conducted using a backwards elimination method. In this method every variable with the highest $P$-value was removed until only variables with a $P$-value $<0.05$ remained in the final model. Interactions were tested between all main effects remaining in the model. A variable was considered significant when the $P$ value was $<0.05$ (Wald's-test). Normality of the data was checked on the residuals. Both Skewness and Kurtosis were between -1 and +1 . The adjusted $\mathrm{R}^{2}$ was calculated as a measure of the fit of the model to explain the amount of variation explained by the model. Farms were divided into three BMSCC categories for this analysis (low: $<150,000$ cells $/ \mathrm{ml}$, medium: $150,000$ to 250,000 cells $/ \mathrm{ml}$, and high: $>250,000$ cells $/ \mathrm{ml})$.

After natural logarithmic transformation, SCC in CNS-positive and culture-negative quarters was compared. Because of the low number of quarters included in this part of the analysis, a the two-sample $t$-test was done, using Statistix 8.0 (Analytical Software, Tallahassee, FL). Statistical significance was defined at $P<0.05$.

\section{Results}

\subsection{Prevalence of CNS}


In total, 4220 quarter milk samples were collected. Coagulase-negative staphylococci

2 were the most frequently isolated group of bacteria. Corrected for the proportion of HSCC and LSCC cows sampled per herd, the average national herd prevalence of CNS IMI in The Netherlands was 10.8\% (95\% CI: 8.5-13.8\%) at quarter level, and 34.4\% (95\% CI: $31.5-$ $37.3 \%$ ) at cow-level (at least one quarter CNS-positive). The corrected cow level prevalence

\subsection{Distribution of CNS}

Prevalence of CNS IMI differed considerably among parity groups. Of the 290 heifers included in the study, $49.4 \%$ had one or more quarters shedding CNS (Figure 1). This was significantly different from second to fifth parity cows.

In three of the 160 milk samples that were re-cultured for CNS identification, $S$. aureus was found, two samples showed no growth. In the remaining 155 samples $14 \mathrm{CNS}$ species were identified with the API Staph ID 32 (Table 2). The most frequently isolated CNS species was $S$. chromogenes (30.3\%) followed by S. epidermidis $(12.9 \%)$ and $S$. capitis $(11.0 \%)$.

Quarters with CNS IMI had a geometric mean SCC of 109,000 cells/ml; almost twice as high as culture-negative quarters, which had a SCC of 58,000 cells $/ \mathrm{ml}(P<0.0001)$ (Table 2). Staphylococcus chromogenes, $S$. capitis and $S$. xylosus had a significant higher SCC than culture-negative quarters $(P<0.05)$, while $S$. epidermidis and $S$. hyicus tended to have a higher SCC than culture-negative quarters $(P=0.05)$ (Table 2$)$. 


\subsection{Risk factors}

(n)

A total of 18 variables entered the multivariate analysis (Table 3). The final model to analyze the results of the questionnaire explained $50 \%$ of the variation of the data; the adjusted $\mathrm{R}^{2}$ had a value of 0.50 (Table 4 ). Factors that significantly contributed to the final model associated with a high prevalence of CNS IMI were source of drinking water not being tap water $(P=0.0004)$, housing of dry cows in one group $(P=0.01)$, measurement of cow SCC every month $(P=0.03)$, udder health monitoring by the veterinarian $(P=0.001)$, pasturing during the outdoor season $(P=0.01)$, percentage of stalls contaminated with milk after milk leaking $(P=0.046)$, and BMSCC $>250,000$ cells $/ \mathrm{ml}(P=0.002)$. No interactions could be included in the final model due to multicollinearity. The constant had a negative value of 47.6\%. This constant together with the coefficients of the risk factors that apply to a herd provides the predicted herd prevalence. For example, a herd with its own water source, where udder health is monitored by the veterinarian, dry cows are housed in two groups, cows have restricted pasturing, SCC is measured, BMSCC is between 150,000 and 250,000 cells $/ \mathrm{ml}$, and no stalls are contaminated with milk would have an estimated prevalence of:

$-47.6+8.1+20.1+0+22.2+38.7-7=34.5 \%$

\section{Discussion}

This is the first time prevalence of CNS has been determined in Dutch dairy cows. However, in non random quarter milk samples of high SCC cows submitted to the GD Animal Health Service, CNS prevalence increased considerably in the last decade and has become the most frequently isolated pathogen (Sol, 2002). In our current study, CNS were 
1 also the most frequently isolated group of bacteria (calculated national quarter prevalence $2 \quad 10.8 \%$ ). World-wide, only very few true random prevalence studies on CNS have been 3 conducted (Pitkälä et al., 2004; Østerås et al., 2006; Bradley et al., 2007). In Finland (16.6\%) 4 and in England and Wales (14.9\%) CNS was the most frequently isolated group of organisms 5 (Pitkälä et al., 2004; Bradley et al., 2007). In Norway, only 3.3\% of quarters were identified 6 as positive for CNS. In the Finnish study, as in our study, a sample was considered CNS7 positive when $\geq 500 \mathrm{cfu} / \mathrm{ml}$ was found (Pitkälä et al., 2004), while in the Norwegian study a sample was CNS IMI with $\geq 4000 \mathrm{cfu} / \mathrm{ml}$ (Østerås et al., 2006). International agreement on the definition of a CNS IMI sample would make studies more comparable. When comparing results of clinical trials and other studies, it should be realized that there may be differences in 11 selection criteria for herds and animals, sampling techniques, and laboratory procedures (Barkema et al., 2006). The definition of a positive sample is just one of them. In our study, more quarters of heifers compared to older cows had CNS IMI. This finding is consistent with earlier studies (Oliver and Mitchell, 1983; Hogan et al., 1987; Rainard et al., 1990; Matthews et al., 1992). Prevalence of CNS IMI is already high in heifers around their first calving (Borm et al., 2006). The lower prevalence of CNS in multiparous cows may be explained by the fact that these cows were dried off with antibiotics and postmilking teat disinfection was applied twice a day during lactation. More than $80 \%$ of the farms in our study used these practices.

The CNS are a heterogeneous group of organisms. Currently, the genus 21 Staphylococcus consists of more than 40 species (Devriese et al., 2002). Coagulase-negative staphylococcus species differ from each other in antimicrobial susceptibility, virulence factors and host response to infection (Birgersson et al., 1992; Devriese et al., 2002). Thus, identification of species may be important for epidemiological investigations, for assessment of their pathogenic significance and for developing specific management practices to prevent 
1 mastitis. Although the identification of this group of organisms is important, it is difficult and relatively costly. For these reasons many laboratories do not include identification of CNS in their routine procedures. In our study, a commercial test kit, API Staph ID 32 test, was used to identify the CNS species. The API Staph ID 32 test is mainly based on human CNS strains and a limited number of veterinary strains (Bes et al., 2000). Nevertheless, in a study in Finland the API Staph ID 32 had an accuracy of 70 to $80 \%$ on bovine mastitis isolates with $90 \%$ probability in comparison with the amplified fragment length polymorphism (Taponen et al., 2006).

Staphylococcus chromogenes, S. epidermidis and S. capitis were the most frequently isolated species. Although in other studies in which species identification was done, cows were not randomly selected, they confirmed this finding (Harmon and Langlois, 1995; Oliver and Jayarao, 1995; Taponen et al., 2006). In older studies, other CNS species such as $S$. hyicus were isolated more frequently (Watts and Owens, 1989), which may be due to misidentification with identification methods used in the eighties (Bes et al., 2000). Additionally, at that time, S. chromogenes was still characterized as S. hyicus. SCC of quarters with CNS IMI was twice as high as SCC of culture-negative quarters in our study and in studies by others (Hogan et al., 1987; Honkanen-Buzalski, 1990; Harmon and Langlois, 1995). Countries with a lower average BMSCC are more likely to culture CNS because cows with a mild increase of SCC are more frequently selected for culturing. The effect of CNS IMI on SCC differs among species (Watts and Owens, 1989). We found significant differences in SCC between culture-negative quarters and infected quarters with five CNS species (Table 2). Most species, however, were found in such low prevalence, that the power to determine differences in SCC was lacking.

The test used in this study to speciate CNS was the API Staph ID 32 test. Research that was carried out after this study was finalized suggests that this test is not the best test to 
1 use for identification of CNS. Nevertheless, based on the distribution and the effect on SCC

2 we suggest that $S$. chromogenes, $S$. epidermidis, $S$. capitis and $S$. xylosus are the most important CNS species in The Netherlands. Further research on pathogenic significance and species specific risk factors should be focused on these pathogens.

Control programmes reduced the prevalence of major pathogens such as $S$. aureus and Strep. agalactiae in The Netherlands (Sampimon et al., 2007b). In our study, the five point programme was carried out by most of the farmers. The five-point plan has an effect on major pathogens (Neave et al., 1969) and presumably also in minor pathogens (Lam et al., 1997a). In spite of this the prevalence per herd varied markedly. Apparently other factors than the five-point plan also influence the CNS prevalence.

Udder health monitoring by the veterinarian and measuring SCC on a regular basis were significantly correlated with an increased prevalence of CNS IMI. This relation may be due to confounding, because we found a high CNS prevalence in herds with BMSCC > 250,000 cells $/ \mathrm{ml}$. It may be hypothesized that herds with relatively high SCC and prevalence of CNS IMI take action to improve udder health. Since our study is a prevalence study we cannot determine the effect of these monitoring activities on CNS infections in the long run.

The impact of CNS on the level of BMSCC is not well-documented in literature. In a study of Rainard et al. (1990), the major pathogens contributed $46 \%$ of the SCC in the BMSCC, while CNS contributed $18 \%$ of the SCC in BMSCC. In our study, a high BMSCC $(>250,000$ cells $/ \mathrm{ml})$ was associated with a higher prevalence of CNS IMI on a farm. In farms with a BMSCC $>250,000$ cells $/ \mathrm{ml}$ a number of recommended procedures such as blanket dry cow therapy, post-milking teat disinfection, treatment regime of clinical cases and hygiene management may not be optimally practiced (Barkema et al., 1999). When bonuses for low BMSCC are given and when the prevalence of major pathogens in a herd is low, the impact of 
1 CNS IMI on SCC will become more important. This means that CNS IMI may become more important on farms with a low BMSCC.

Using one instead of two groups of dry cows increased the prevalence of CNS IMI on a farm. Forming two groups of dry cows, far off and close-up, is necessary to avoid problems with milk leaking and to support a better feeding program (Barkema et al., 1999). Our data confirm this finding; we found a higher prevalence of CNS IMI in herds with more stalls contaminated with milk. Where farms manage dry cows as a single group, heifers and closeup cows are often be housed in the lactating group for several weeks before parturition. This may increase leaking of milk, and have an effect on udder edema due to high protein intake. Heifers with udder edema were 1.65 times more likely to develop clinical mastitis (Waage et al., 2001).

Drinking water from another source than tap water during the indoor season increased prevalence of CNS IMI. These 'other' water sources may have increased the exposure to dirt. Providing water from another source than tap water was also identified as a risk factor for environmental clinical mastitis in two other Dutch studies (Schukken et al., 1990; Barkema et al., 1999). This could be an indication that CNS can act as an environmental pathogen. In our study, the mixed sources of water, including tap water were associated with a lower prevalence of CNS IMI. We have no clear explanation for this, but it may be so that farmers using tap water use more hygienic management procedures on their farms than farmers using only ditch water as drinking water.

Pasturing during the outdoor season was associated with an increased prevalence of CNS IMI on a farm. The summer period is the period when flies are active. Flies, especially the hornfly Haematobia irritans can transmit S. aureus (Owens et al., 1998). This biting fly is very common in The Netherlands and it is possible that it also transmits CNS. 
In our study, data from 49 farms were analyzed for possible risk factors associated

2 with prevalence of CNS IMI. Source of drinking water, housing dry cows in one group and

3 pasturing cows were found to be the most significant ones, as were BMSCC and udder health

4 monitoring activities.

\section{Conflict of interest}

None of the authors (O.C. Sampimon, H.W. Barkema, I.M.G.A. Berends, J. Sol,

T.J.G.M. Lam) has a financial or personal relationship with other people or organizations that

11 could inappropriately influence or bias the paper entitled "Prevalence and herd-level risk

12 factors for intramammary infection with coagulase-negative staphylococci in Dutch dairy 13 herds".

\section{Acknowledgments}

17

\section{References}


1 Barkema, H. W., Schukken, Y.H., Lam, T. J., Beiboer, M. L., Wilmink, H., Benedictus, G., Brand, A., 1998, Incidence of clinical mastitis in dairy herds grouped in three categories by bulk milk somatic cell counts. J. Dairy Sci. 81, 411-419.

Barkema, H.W., Schukken, Y.H., Lam, T.J.G.M., Beiboer, M.L., Benedictus, G., Brand, A., 1999, Management practices associated with the incidence rate of clinical mastitis. J. Dairy Sci. 82, 1643-1654.

Barkema, H.W., Schukken, Y.H., Zadoks, R.N., 2006, Invited review: The role of cow, pathogen, and treatment regimen in the therapeutic success of bovine Staphylococcus aureus mastitis. J. Dairy Sci. 89, 1877-1895.

Bes, M., Guerin-Faublee, V., Meugnier, H., Etienne, J., Freney, J., 2000, Improvement of the identification of staphylococci isolated from bovine mammary infections using molecular methods. Vet. Microbiol. 71, 287-294.

Birgersson, A., Jonsson, P., Holmberg, O., 1992, Species identification and some characteristics of coagulase-negative staphylococci isolated from bovine udders. Vet. Microbiol. 31, 181-189.

Borm, A.A., Fox, L.K., Leslie, K.E., Hogan, J.S., Andrew, S.M., Moyes, K.M., Oliver, S.P., Schukken, Y.H., Hancock, D.D., Gaskins, C.T., Owens, W.E., Norman, C., 2006, Effects of prepartum intramammary antibiotic therapy on udder health, milk production, and reproductive performance in dairy heifers. J. Dairy Sci. 89, 2090-2098.

Bradley, A.J., Leach, K.A., Breen, J.E., Green, L.E., Green, M.J., 2007, Survey of the incidence and aetiology of mastitis on dairy farms in England and Wales. Vet. Rec. 160, 253-257.

Bramley, A.J., Dodd, F.H., 1984, Reviews of the progress of dairy science: mastitis control progress and prospects. J. Dairy Res. 51, 481-512. 
1 De Vliegher, S., Laevens, H., Devriese, L.A., Opsomer, G., Leroy, J.L., Barkema, H.W., de

2 Kruif, A., 2003, Prepartum teat apex colonization with Staphylococcus chromogenes in 3 dairy heifers is associated with low somatic cell count in early lactation. Vet. Microbiol. $92,245-252$.

De Vliegher, S., Opsomer, G., Vanrolleghem, A., Devriese, L.A., Sampimon, O.C., Sol, J., Barkema, H.W., de Kruif, A., 2004, In vitro growth inhibition of major mastitis pathogens by Staphylococcus chromogenes originating from teat apices of dairy heifers. Vet. Microbiol. 101, 215-221.

Devriese, L.A., Keyser, H., 1979, Prevalence of different species of coagulase-negative staphylococci on teats and in milk samples from dairy cows. J. Dairy Res. 47, 155-158.

Devriese, L.A., Baele, M., Vaneechoutte, M., Martel, A., Haesebrouck, F., 2002, Identification and antimicrobial susceptibility of Staphylococcus chromogenes isolates from intramammary infections of dairy cows. Vet. Microbiol. 87, 175-182.

Halasa, T., Huijps, K., Østerås, O., Hogeveen, H., 2007, Economic effects of bovine mastitis and mastitis management: A review. Vet. Q. 29, 18-31.

Harmon, R.J., Eberhart, R.J., Jasper, D.E., Langlois, B.E., Wilson, R.A., 1990, Microbiological procedures for the diagnosis of udder infection. National Mastitis Council

Harmon, R.J., Langlois, B.E., 1995, Mastitis due to coagulase-negative Staphylococcus species. In: Proc. 34th Annual Meeting of the National Mastitis Council, Fort Worth, TX, USA, pp. 56-67.

Hogan, J.S., White, D.G., Pankey, J.W., 1987, Effects of teat dipping on intramammary infections by staphylococci other than Staphylococcus aureus. J. Dairy Sci. 70, 873879. 
1 Honkanen-Buzalski, T., 1990, The role of coagulase-negative Staphylococcus species in

2 bovine mastitis. In: Proc. $23^{\text {rd }}$ Annual Conference of the American Association of Bovine 3 Practitioners, Indianapolis, IN, USA, pp. 98-102.

4 Lam, T.J.G.M., Vliet, J.H.v., Schukken, Y.H., Grommers, F.J., Velden-Russcher, A. van,

Neave, F.K., Dodd, F.H., Kingwill, R.G., Westgarth, D.R., 1969, Control of mastitis in the dairy herd by hygiene and management. J. Dairy Sci. 52, 696-707.

Oliver, S.P., Mitchell, B.A., 1983, Intramammary infections in primigravid heifers near parturition. J. Dairy Sci. 66, 1180-1183.

Oliver, S.P., Jayarao, B.M., 1995, Coagulase-negative staphylococcus species intramammary infections in heifers and cows during the nonlactating and perpertum periods. In: Proc of 34th Annual Meeting of the National Mastitis Council, Fort Worth TX, USA, pp. 68-77. 
1 Østerås, O., Sølverød, L., Reksen, O. 2006. Milk culture results in a large Norwegian survey -

2 effects of season, parity, days in milk, resistance, and clustering. J. Dairy Sci. 89, 10101023.

Owens, W.E., Oliver, S.P., Gillespie, B.E., Ray, C.H., Nickerson, S.C., 1998, Role of horn flies (Haematobia irritans) in Staphylococcus aureus-induced mastitis in dairy heifers. Am. J. Vet. Res. 59, 1122-1124.

Piepers, S.L., De Meulemeester, L., De Kruif, A., Opsomer, G., Barkema, H.W., De Vliegher, S., 2007, Prevalence and distribution of mastitis pathogens in subclinically infected dairy cows in Flanders, Belgium. J. Dairy Res., in press.

Pitkälä, A., Haveri, M., Pyörälä, S., Myllys, V., Honkanen-Buzalski, T., 2004, Bovine mastitis in Finland 2001 - prevalence, distribution of bacteria, and antimicrobial resistance. J. Dairy Sci. 87, 2433-2441.

Rainard, P., Ducelliez, M., Poutrel, B., 1990, The contribution of mammary infections by coagulase-negative staphylococci to the herd bulk milk somatic cell count. Vet. Res. Comm. 14, 193-198.

Sampimon, O.C., Vernooij, J.C.A., Mevius, D.J., Sol, J., 2007a, [Sensitivity for various antibiotics of coagulase-negative staphylococci, isolated from milk samples of Dutch dairy cattle]. Tijdschr. Diergeneeskd. 132, 200-204.

Sampimon, O.C., Barkema, H.W. Berends, I.M.G.A., Sol, J., Lam, T.J.G.M., 2007b, Prevalence of intramammary infection in Dutch dairy herds. J. Dairy Sc., accepted.

Schukken, Y.H., Grommers, F.J., v.d. Geer, D., Erb, H.N., Brand, A., 1990, Risk factors for clinical mastitis in herds with a low bulk milk somatic cell count. 1. Data and risk factors for all cases. J. Dairy Sci. 73, 3463-3471.

Smith, K.L., Hogan, J.S., 2001, The world of mastitis. In: Proc. $2^{\text {nd }}$ Intern. Symp. mastitis and milk quality, Vancouver, BC, Canada, September 13-15, pp. 1-12. 
1 Sol, J. 2002, Cure of Staphylococcus aureus mastitis in Dutch dairy cows. PhD-thesis,

2 Utrecht University, Utrecht, The Netherlands.

3 Taponen, S., Simojoki, H., Haveri, M., Larsen, H.D., Pyörälä, S., 2006, Clinical 4 characteristics and persistence of bovine mastitis caused by different species of coagulasenegative staphylococci identified with API or AFLP. Vet. Microbiol. 115, 199-207.

6 Taponen, S., Pyörälä, E., 2007, How important is coagulase-negative staph as a cause of mastitis? In: Proc. 46th Annual Meeting of the National Mastitis Council, San Antonio TX, USA, pp. 81-91.

9 Trinidad, P., Nickerson, S.C., Alley, T.K., 1990, Prevalence of intramammary infection and teat canal colonization in unbred and primigravid dairy heifers. J. Dairy Sci. 73, 107-114.

11 Waage, S., Odegaard, S.A., Lund, A., Brattgjerd, S., Rothe, T., 2001, Case-control study of risk factors for clinical mastitis in postpartum dairy heifers. J. Dairy Sci. 84, 392-399.

Watts, J.L., Owens, W.E., 1989, Prevalence of staphylococcal species in four dairy herds. Res. Vet. Sci. 46, 1-4. 


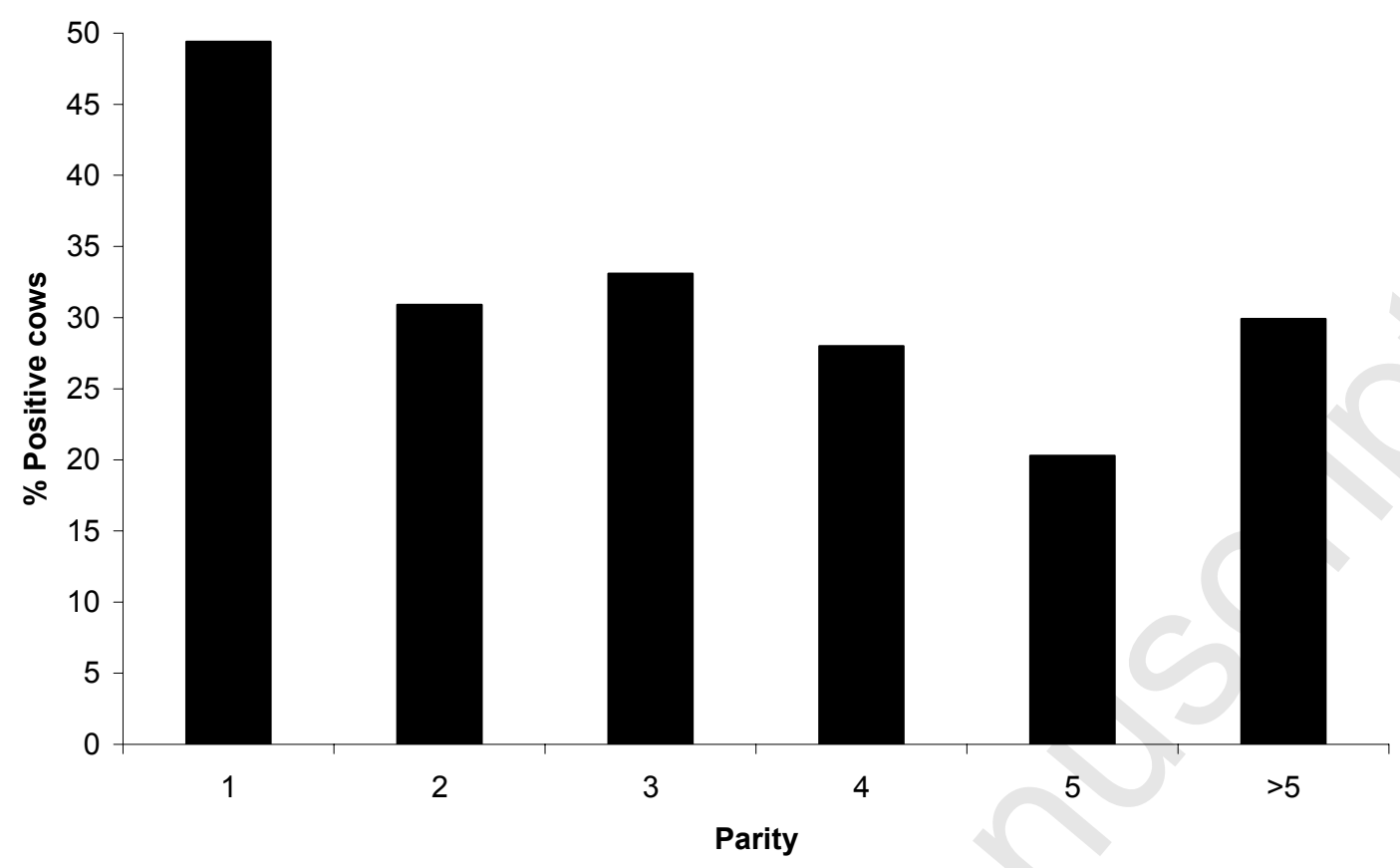

1

$2 \quad$ Fig. 1

3 Parity distribution of coagulase-negative staphylococci IMI at cow level (one or more quarters 4 infected).

5 


\section{$1 \quad$ Table 1}

2 Summary of management factors in the questionnaire.

General

Number of lactating and dry cows, number of cows with low SCC, measuring cow SCC every four weeks by the Dutch DHI, bulk milk SCC category, calving pattern (spring, summer, autumn, winter and year round), udder health monitoring by veterinarian, season of sampling $($ winter $=$ December, January and February; spring $=$ March, April and May; summer = June, July and August; autumn = September, October and November)

Housing Type of barn, type of ventilation, number of stalls, bedding material, facilities housing heifers separately before calving, separate calving pen used, type of flooring

Hygiene Cleaning of calving pen after each calving, percentage of dirty stalls (less than $20 \%$ of the stall contaminated with dirt was determined as clean), percentage of stalls contaminated with milk (counting the number of stalls contaminated with milk during the farm visit), cleaning of stalls each day, cleaning of walking alley each day

Feeding

Percentage of feeding places per cow in the barn, percentage of corn silage in summer ration and winter ration, cows on pasture during outdoor season, hours on pasture, fly control of heifers during outdoor season, number of dry cow groups, supplementation minerals to heifers, dry cows and lactating cows, source of drinking water used in the barn, check of drinking water by laboratory procedures

Young stock Feeding calves milk with antibiotics or high SCC milk, method of feeding milk 
Milking

Milking

procedure

Bacteriology

and

therapy
Type of milking parlor, age of milking parlor, number of clusters, height of milk pipe, milking cows before calving

Method of udder preparation, pre-stripping, post-milking teat disinfection, teat disinfection of dry cows, teat disinfection of heifers before calving, milking high SCC cows last

Mastitis treatment protocol used, summer mastitis prevention by ear tags, regiment of dry cow therapy, treatment of high SCC cows, treatment of clinical mastitis, teat disinfection before treatment, who is conducting bacteriology of high SCC cows 
$1 \quad$ Table 2

2 Distribution of coagulase-negative staphylococci species identified with API Staph ID 32 in

3 quarter milk samples and geometric quarter somatic cell count (SCC; x 1,000 cells/ml).

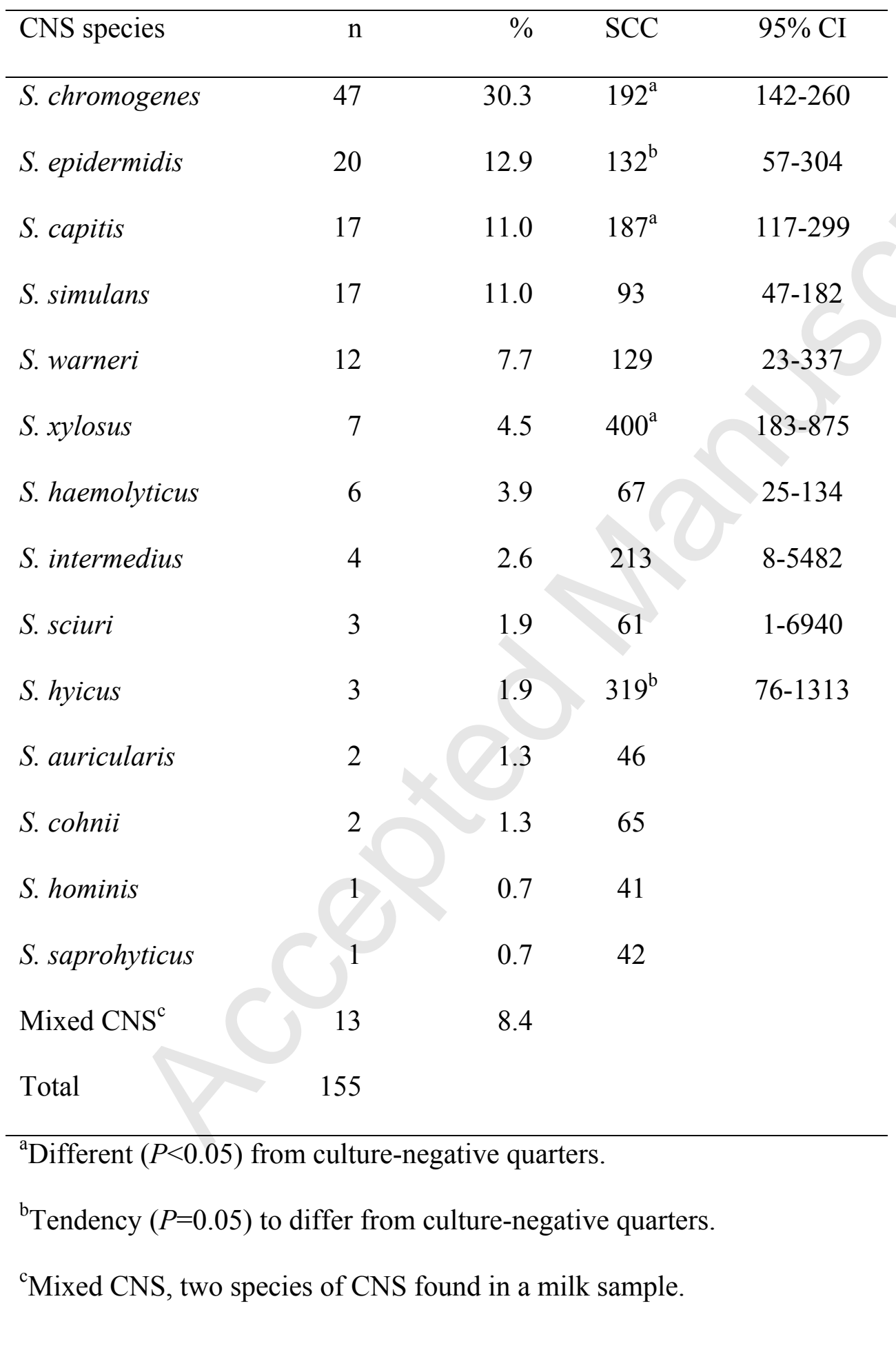




\section{$1 \quad$ Table 3}

2 Management factors associated with the prevalence of coagulase-negative staphylococci

3 intramammary infection (IMI) offered to the final multivariate analysis $(P$-value $<0.25)$.

\begin{tabular}{|c|c|c|c|}
\hline Variables & No. farms & CNS IMI (\%) & $\begin{array}{l}P \text {-value } \\
\text { univariate } \\
\text { analysis }\end{array}$ \\
\hline \multicolumn{4}{|l|}{ General } \\
\hline Herd size & & & 0.20 \\
\hline $\begin{array}{l}\text { Measuring cow SCC on milk } \\
\text { recording }\end{array}$ & & & 0.20 \\
\hline yes & 48 & 32.4 & \\
\hline no & 1 & 6.9 & \\
\hline $\begin{array}{l}\text { Udder health monitoring by } \\
\text { veterinarian }\end{array}$ & & & 0.08 \\
\hline yes & 8 & 45.3 & \\
\hline no & 41 & 29.3 & \\
\hline $\begin{array}{l}\text { Bulk milk SCC category }(* 1000 \\
\text { cells } / \mathrm{ml})\end{array}$ & & & 0.18 \\
\hline$<150$ & 19 & 32.1 & \\
\hline $150-250$ & 17 & 26.0 & \\
\hline$>250$ cells $/ \mathrm{ml}$ & 13 & 39.4 & \\
\hline Season of sampling & & & 0.25 \\
\hline winter & 6 & 32.5 & \\
\hline spring & 19 & 35.9 & \\
\hline summer & 9 & 36.8 & \\
\hline autumn) & 10 & 23.7 & \\
\hline \multicolumn{4}{|l|}{ Housing facilities } \\
\hline Separate calving pen & & & 0.21 \\
\hline yes & 36 & 29.8 & \\
\hline no & 13 & 37.8 & \\
\hline \multicolumn{4}{|l|}{ Hygiene } \\
\hline $\begin{array}{l}\text { Percentage of stalls contaminated } \\
\text { with milk }\end{array}$ & & & 0.25 \\
\hline \multicolumn{4}{|l|}{ Feeding } \\
\hline Feeding places per cow & & & 0.08 \\
\hline Cows on pasture during summer & & & 0.10 \\
\hline $\begin{array}{l}\text { unrestrained } \\
\text { restrained (part of the day) }\end{array}$ & $\begin{array}{l}20 \\
25\end{array}$ & $\begin{array}{l}33.2 \\
38.2\end{array}$ & \\
\hline no & 2 & 33.2 & \\
\hline part of season restricted & 2 & 63.3 & \\
\hline Dry cows housed in two groups & & & 0.10 \\
\hline yes & 28 & 27.9 & \\
\hline no & 21 & 37.9 & \\
\hline Heifers on pasture during summer & & & 0.17 \\
\hline yes & 43 & 33.3 & \\
\hline no & 6 & 21.6 & \\
\hline Source of drinking water used in the & & & 0.11 \\
\hline
\end{tabular}


barn

ditch water

44.1

tap water

28.7

own well water source

33.4

other water source

2.4

multiple answers

Milking

Type of milking parlor

tie stall

herringbone

side by side

tandem

10.4

automatic milking system

rotor parlor

$\begin{array}{rr}1 & 2.4 \\ 2 & 10.4\end{array}$

Milking procedure

Teat disinfection of heifers before calving

yes

no

Teat disinfection of dry cows

yes

no

Complete milk out directly after calving

yes

no

30

Bacteriology and therapy

Mastitis treatment protocol used yes

no

own insight

Who is conducting bacteriology of

high SCC cows

veterinary practitioner

animal health service

both

nobody
32.9

40.5

0.01

\subsection{5}

0.15

25.6

32.5

0.10

26.8

35.7

0.05

53.6

28.5

30.9

0.10 


\section{$1 \quad$ Table 4}

2 Final linear regression model for the prevalence of coagulase-negative staphylococci.

\begin{tabular}{llrrr}
\hline Variable & Category & Estimate & SE & $P$-value (t) \\
\hline Constant & & -47.6 & \\
Source of drinking water & tap water & reference & \\
used in the barn & ditch water & 23.4 & 7.3 & 0.003 \\
& own well water source & 8.1 & 4.7 & 0.093 \\
& combination of tap water & -19.3 & 15.5 & 0.223 \\
& with ditch or own well & & & \\
& water source & & & \\
& other & -37.1 & 11.5 & 0.003
\end{tabular}

Udder health monitored by no

reference

veterinarian

yes

Dry cows housed in two

yes

groups

reference

$\begin{array}{lll}11.4 & 4.3 \quad 0.012\end{array}$

Pasturing during outdoor

no

reference

season

$$
\begin{aligned}
& \text { yes } \\
& \text { restrained } \\
& \text { part of the season restricted }
\end{aligned}
$$

Measuring cow SCC at

no

$18.4 \quad 11.6$

$22.2 \quad 12.2$

0.079

$55.0 \quad 16.2$

0.002

reference

milk recording 
yes

Bulk milk SCC $($ cells $/ \mathrm{ml}) \quad<150,000$

$150,000-250,000$

$>250,000$

Percentage of stalls

contaminated with milk $\begin{array}{lll}38.7 & 17.2 & 0.031\end{array}$

reference

$\begin{array}{rrr}-7.0 & 5.0 & 0.17 \\ 15.6 & 6.0 & 0.014\end{array}$

$\begin{array}{lll}1.3 & 0.6 & 0.046\end{array}$ 